\title{
A LEGELTETÉSES ÁLLATTENYÉSZTÉS MEGHONOSÍTÁSÁNAK LEHETŐSÉGEI ÉS KORLÁTAI SOMOGY MEGYÉBEN
}

\author{
(The possibilities and limits of introducing grazing animal \\ husbandry in Somogy county)
}

BOKORNÉ KITANICS TÜNDE

\section{Somogy megye ökológiai adottságai}

Somogy megye terủletének mintegy kétharmada dombvidék. Ezek közül délkeleten a Mecsek nyúlványaként folytatódó Zselic és az északkeleten elhelyezkedö Tabidombvidék a legnagyobb. Mindkét tájegység felszíne erösen szabdalt. A szúk vőlgyek, meredek domboldalak, a sok patakvölgy és szurdok e terủleteket a nagyüzemi termelés számára nehezen hozzáférhetỏvé teszik.

A talajok ötféle alapközeten alakultak ki: 53\%-ban löszön, 30\%-ban homokon, 8\%ban folyami üledéken, 5\%-ban agyagon és 4\%-ban pedig lápon és tőzegen. Az alapkőzeten meghatározza a talajminőséget, de megfelelő mủveléssel, másodlagos anyagok adagolásával és a talajviszonyokhoz alkalmazkodó technológiával a termésátlagok eltérőek lehetnek. Somogyra bár elsősorban az erdőtalajok és a csernozjomok jellemzöek, a nyugati részen kialakult barna erdőtalajoktól a keleti csernozjomig mégis a teljes talajsorozat fellelhető. A legjobb szántóföldek a Mezőföldön, a Kaposvölgyben és a Marcaliháton találhatók. A többi körzet talajai gyengébb minőségúek.

$\mathrm{Az}$ 1. táblázat láthatóvá teszi az oŕszág nagyobb tájkörzeteinek csapadékeloszlását havi bontásban. Legtöbb csapadék Nyugat-Dunántúlon és Dél-Dunántúlon esett. Évente három csapadék maximum van: február, május-június és szeptember-október körül. A táblázatból számított szórásértékek alapján megállapítottam, hogy a csapadék eloszlása Dél-Dunántúlon és Kelet-Magyarországon a legegyenletesebb.

A Dél-Dunántúl csapadékeloszlása jellemző Somogy megyére is. A csapadék évi mennyisége a megyében $550-880 \mathrm{~mm}$. Az átlagos csapadékmennyiség délnyugatról északkelet felé haladva egyre csőkken. A Dráva mentén és a Homokvidék déli részén $750-800 \mathrm{~mm}$ csapadék hull évente. A Mezőföld somogyi része viszont az évi 500-550 mm-es csapadékával a megye legszárazabb körzetének számít (1. ábra).

A napfényes órák száma 1850-2000 kőzo̊tt alakul és földrajzilag a csapadékeloszlással ellentétes irányba változik.

A megye területén az évi átlagos kőzéphörmékséklet $9,5-10^{\circ} \mathrm{C}$ kőzött van. 
Bokorné Kitanics Tünde : A legeltetéses állattenyésztés meghonositásának lehetöségei és korlátai Somogy megyében Tér és Társadalom 10. évf. 1996/4. 113-123. p.

114 Bokorné Kitanics Tünde

TÉT 1996 - 4

\section{TÁBLÁZAT}

A nagyobb tájegységekre jellemzö csapadék mennyisége és eloszlása (10 éves átlag) (Quantity and breakdown of precipitation in the main small regions [average of ten years])

(milliméter)

\begin{tabular}{|l|c|c|c|c|c|c|c|c|c|c|c|c|c|}
\hline \multicolumn{1}{|c|}{ Tájegység } & \multicolumn{10}{|c|}{ Hónapok } & Összesen \\
\cline { 2 - 12 } & I. & II. & III. & IV. & V. & VI. & VII. & VIII. & IX. & X. & XI. & XII. & \\
\hline Észak-Dunántúl & 32 & 83 & 55 & 30 & 57 & 71 & 26 & 34 & 70 & 25 & 26 & 42 & 55 I \\
Nyugat-Dunántúl & 59 & 68 & 52 & 31 & 70 & 74 & 60 & 73 & 9 I & 95 & 48 & 41 & 760 \\
Dél-Dunántúl & 48 & 56 & 49 & 35 & 65 & 72 & 56 & 68 & 82 & 83 & 35 & 39 & 688 \\
Dunántúl átlag & 46 & 65 & 52 & 33 & 66 & 72 & 44 & 59 & 81 & 66 & 33 & 40 & 666 \\
Duna-Tisza koze & 31 & 44 & 41 & 40 & 77 & 81 & 32 & 28 & 58 & 36 & 28 & 24 & 550 \\
Észak-Magyarország & 28 & 52 & 48 & 43 & 75 & 86 & 52 & 37 & 54 & 34 & 35 & 28 & 572 \\
Kelet-Magyarország & 25 & 38 & 42 & 35 & 81 & 80 & 48 & 43 & 55 & 41 & 38 & 39 & 565 \\
Nagyalfôld (Szolnok) & 29 & 36 & 38 & 33 & 85 & 78 & 44 & 28 & 42 & 35 & 39 & 26 & 513 \\
\hline
\end{tabular}

Forrás: KSH

\section{1. ÁBRA}

Évi csapadékeloszlás a Dél-Dunántúlon

(Annual precipitation in South Transdanubia)

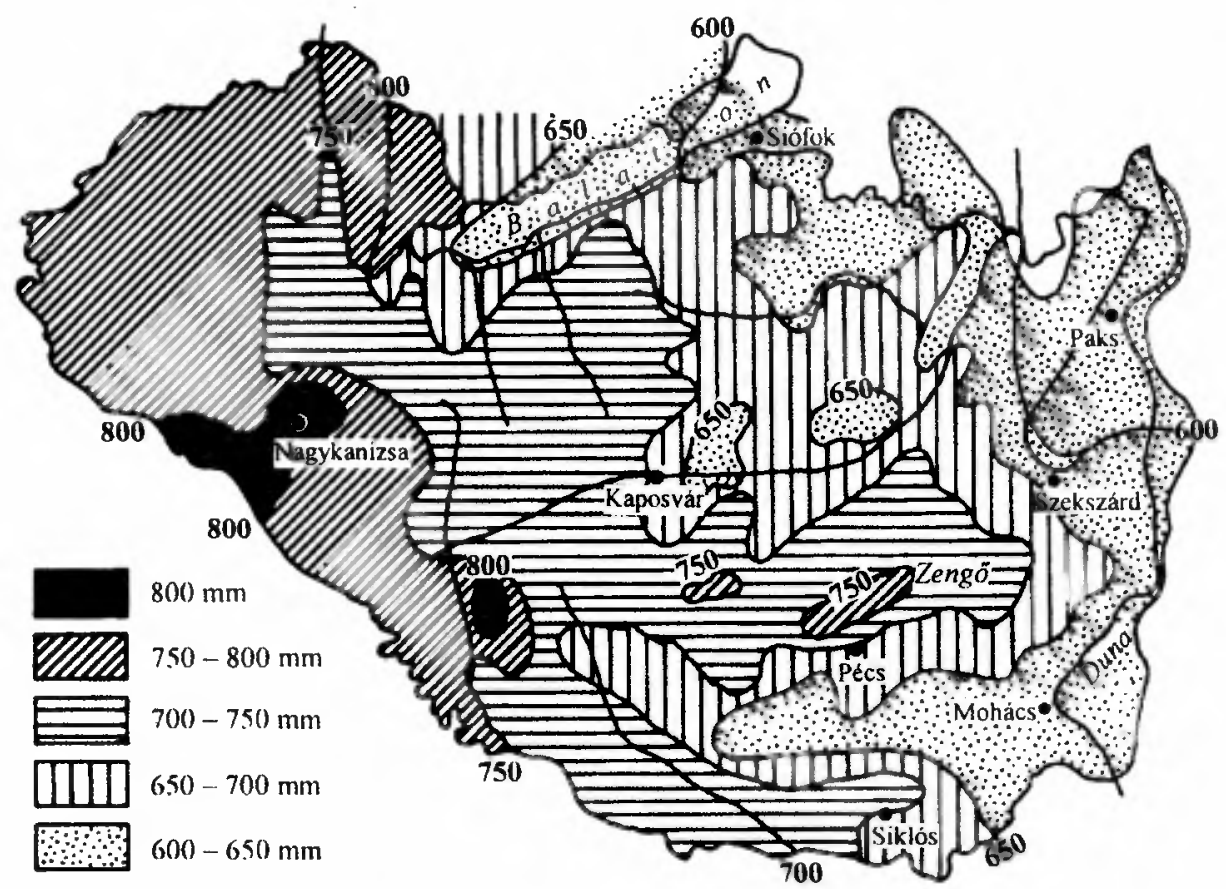

Forrás: Magyarország Éghajlati Atlasza 
Bokorné Kitanics Tünde : A legeltetéses állattenyésztés meghonosításának lehetöségei és korlátai Somogy megyében Tér és Társadalom 10. évf. 1996/4. 113-123. $p$.

TÉT 1996 - 4 A legeltetéses állattenyésztés meghonositásának lehetöségei...

115

\section{A mưvelési ágak megoszlása Somogy megyében}

Somogy megye az ország összes földterületének 6,1\%-át foglalja magában. Hasonló arányt képvisel a termőterület is (6,3\%). A földterület múvelési ágak szerinti megoszlását mutatja a 2. táblázat. 1980 és 1994 között a szántó aránya először (1993-ig) csökkent, majd nőtt. E múvelési ág aránya Somogyban az országosnál alacsonyabb.

A gyepterületek rohamos mértékben csökkentek, 75 ezer ha-ról 57 ezre ha-ra. Részarányuk Somogyban szintén az országos átlag alatt van.

\section{TÁBLÁZAT}

Földterület múvelési ágak szerint (május 31.)

[Breakdown of lands by branch of cultivation (31. May)]

\begin{tabular}{|c|c|c|c|c|c|}
\hline Müvelési ág & 1980 & 1990 & 1992 & 1993 & 1994 \\
\hline Szántó & 268.754 & 265364 & 264401 & 262987 & 263430 \\
\hline Kert & 20545 & 25491 & 2133 & 2133 & 2122 \\
\hline Gyumolcsos & 6674 & 4532 & 4373 & 3957 & 3956 \\
\hline Szölö & 5995 & 6230 & 6279 & 6012 & 6019 \\
\hline Gyep & 75087 & 59338 & 57816 & 57758 & 57007 \\
\hline Mezógazdasági terület & 377055 & 360955 & 335002 & 332847 & 332534 \\
\hline Erdỏ & 148607 & 149755 & 151194 & 166121 & 166705 \\
\hline Nádas & 2182 & 2976 & 2891 & 2911 & 3339 \\
\hline Termő́teriłlet & 530741 & 516671 & 492049 & 504942 & 505734 \\
\hline Müvelés alól kivett terulet & 69831 & 85509 & 74968 & 62397 & 63249 \\
\hline Összesen & 600572 & 602180 & 567017 & 567339 & 568983 \\
\hline
\end{tabular}

Az erdő terủlete nơvekedett mintegy 18 ezer hektárral. E múvelési ág az, amelynek terủleti részesedése jóval az országos átlag felett van, 29\%-os részarányát egyedủl az ország északi régiója közelíti meg.

A mủvelési ágak tájkörzetenkénti megoszlását mutatja a 3. táblázat. Országos átlag feletti a szántó aránya a Kapos-völgyébén (62\%). A szántók helyzete általában kedvező, egybevág a domborzati viszonyok alakulásával. A „képet” a dombvidékek rontják le, ahol sok kisméretủ szántó ékelődik a gyepek és az erdők kỏzé. Legnagyobb arányú a gyep (21\%) a Zselicben. Országos átlag körủli a Marcali-háton (12,5\%) és a Somogyihomokvidéken (10\%). A gyepek változatos területi képet mutatnak. Legnagyobbrészt vízfolyások mentén fordulnak elö, illetve a nehezen müvelhető, gyengébb talajminöségü lejtös domboldalakon.

Az erdő részaránya a Zselicben (40\%), messze felülmúlja mind az országos, mind a megyei átlagot. Az átlagnál (országos és megyei) jóval nagyobb a Dráva melléke és a Somogyi-homokvidék erdősültsége is.

A 2. ábrán a 17 AK-nál gyengébb minőségú fỏldek láthatók. Ezek nagyobb részben a Somogyi-homokvidéken, a Zselicségben és a Tabi-dombvidéken találhatók. Szembetünő, hogy az (általam megjelölt) 50\%-nál magasabb területi arányt képviselő szántók milyen nagy teruleten találhatók e gyenge (17 AK alatti) minóségü talajokon. Mind ökológiai, mind okonómiai megfontolásból ajánlatos lenne, hogy e gyenge termőképességü szántók helyett gyepeket telepítsenek. 
Bokorné Kitanics Tünde : A legeltetéses állattenyésztés meghonosításának lehetöségei és korlátai Somogy megyében Tér és Társadalom 10. évf. 1996/4. 113-123. p.

\section{TÁBLÁZAT}

Földterület megoszlása müvelési ágak szerint, területi részletezésben*

(1991. március 31.)

(Breakdown of lands by branch of cultivation, in territorial division [31. March 1995])

\begin{tabular}{|c|c|c|c|c|c|c|c|c|}
\hline $\begin{array}{l}\text { Mezőgazdasági tảj- } \\
\text { körzet }\end{array}$ & Szántó & $\begin{array}{c}\text { Kert, } \\
\text { gyümöles } \\
\text { os }\end{array}$ & Szölö & Gyep & $\begin{array}{c}\text { Mezŏgaz } \\
\text { dasági } \\
\text { terulet }\end{array}$ & Erdỏ & $\begin{array}{c}\text { Termóter } \\
\text { ullet }\end{array}$ & $\begin{array}{c}\text { Összes } \\
\text { foldterule } \\
t\end{array}$ \\
\hline Mezöfold Hil. & 38,1 & 6,2 & 1,8 & 6,0 & 52,1 & 15,0 & 67,8 & 100,0 \\
\hline Kaposvőlgye & 62,1 & 6,0 & 0,8 & 7,0 & 75,9 & 12,3 & 88,2 & 100,0 \\
\hline Marcali-hát & 35,1 & 5,9 & 1,7 & 12,5 & 55,2 & 21,0 & 78,2 & 100,0 \\
\hline Dráva melléke & 39,5 & 4,5 & 0,5 & 8,5 & 53,0 & 29,0 & 82,1 & 100,0 \\
\hline Tabi dombvidék & 47,0 & 6,3 & 1,7 & 8,6 & 63,6 & 22,2 & 86,6 & 100,0 \\
\hline Zselic & 28,0 & 5,1 & 0,5 & 21,0 & 54,6 & 40,0 & 94,6 & 100,0 \\
\hline Somogyí homokvidék & 44,0 & 4,6 & 0,5 & 10,0 & 59,1 & 28,4 & 87,7 & 100,0 \\
\hline Megyei átlag & 44,1 & 4,9 & 1,0 & 9,8 & 59,8 & 24,9 & 85,7 & 100,0 \\
\hline Elmaradott térségek & 38,4 & 4,1 & 1,2 & 13,5 & 57,2 & 29,3 & 87,3 & 100,0 \\
\hline Országos átlag & 50,7 & 4,7 & 1,5 & 12,7 & 69,6 & 18,2 & 88,5 & 100,0 \\
\hline
\end{tabular}

*Kozségsoros adatok

Forrás: KSH Somogy Megyei igazgatósága AMÖ tablók. Mezőgazdasági Statisztikai Zsebkőnyv, KSH, Budapest, 1991.

A 3. ábrån a legelök elhelyezkedését térképeztem fel a jobb (17 AK feletti) minöségü talajokon. Egyedül a Marcali-háton található nagyobb arányban gyep (Balaton mentén) e jobb termőképességü földeken is. Ebből következik, hogy a gyepek nagyobb arányban a rosszabb minóségü talajokon találhatók.

A gyep arányának növelése a megyében indokolt lenne. A lejtỏs szántó müvelése sok nehézséggel jár, nagy a talaj lemosódásának veszélye, a termések kisebbek, mint a sík területeken. A lejtőn a gyep a legmegfelelőbb talajvédő. A lejtő 1\%-a a gyep termését 1,6-2,0\%-kal csökkenti, ami kevesebb a szántóföldinél, mert ott a lejtó 1\%-a 2,4-2,7\%os terméscsökkenést jelent. Ezek a tények igazolják az ökológiához igazítctt termelésszerkezetet. Ezért a 15\%-nál nagyobb lejtésú szántókat gyepesítésre, a 25 foknál meredekebb részeket erdősítésre javasolnám. A lejtőkön, domboldalakon megfelelő hozzáértéssel és mủvelési móddal gazdaságos legeltetéses állattartás valósítható meg.

\section{Az állattartás Somogy megyében}

1996. március 31-én a megyében 40000 szavasmarha és ebböl 18000 tehén volt. A 4. táblázat mezőgazdasági tájkörzetenként mutatja az állatállomány megoszlását.

Legtöbb szarvasmarha a Somogyi homokvidéken és a Tabi dombvidéken található. Ugyanitt koncetrálódott a juh-és a lóállomány is.

Szembetủnö, hogy a megye legnagyobb összefüggö gyepterületével rendelkezó Zselicségben tenyésztik a legkevesebb szarvasmarhát. Ez a tény is a gyepterületek folyamatos „leértékelỏdését” mutatja, illetve azt, hogy a legelóre alapozott szarvasmarhatartást majdnem teljes mértékben felszámolták. Ennek a tartástechnológiának a „visszahonosítása” a megye mezőgazdaságának stratégiai feladata lenne. 
Bokorné Kitanics Tünde : A legeltetéses állattenyésztés meghonositásának lehetőségei és korlátai Somogy megyében Tér és Társadalom 10. évf. 1996/4. 113-123. p.

TÉT 1996 - $4 \quad$ A legeltetéses állattenyésztés meghonositásának lehetöségei... 117

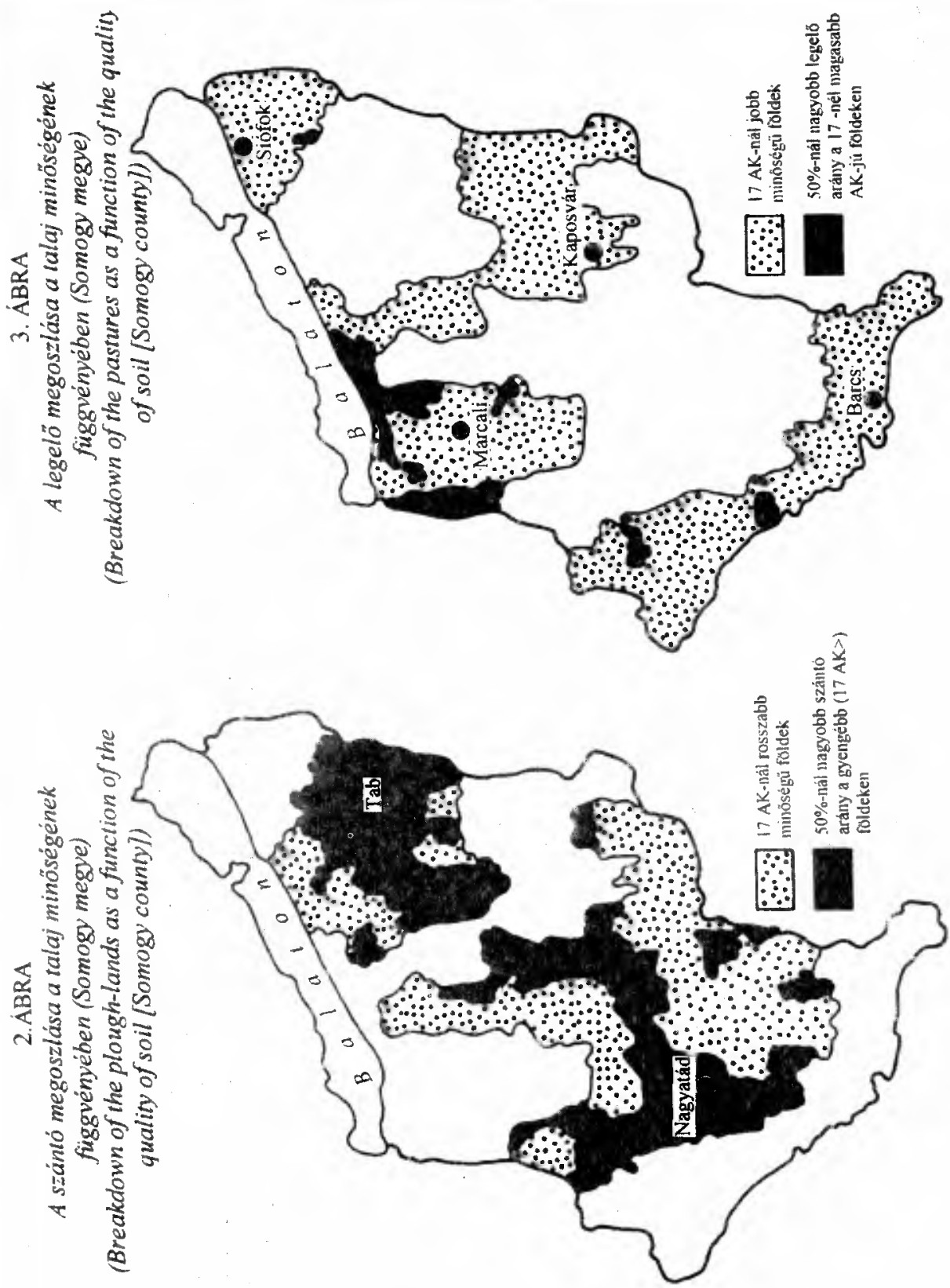


Bokorné Kitanics Tünde : A legeltetéses állattenyésztés meghonositásának lehetőségei és korlátai Somogy megyében Tér és Társadalom 10. évf. 1996/4. 113-123. p.

\section{Bokorné Kitanics Tünde}

TÉT 1996 : 4

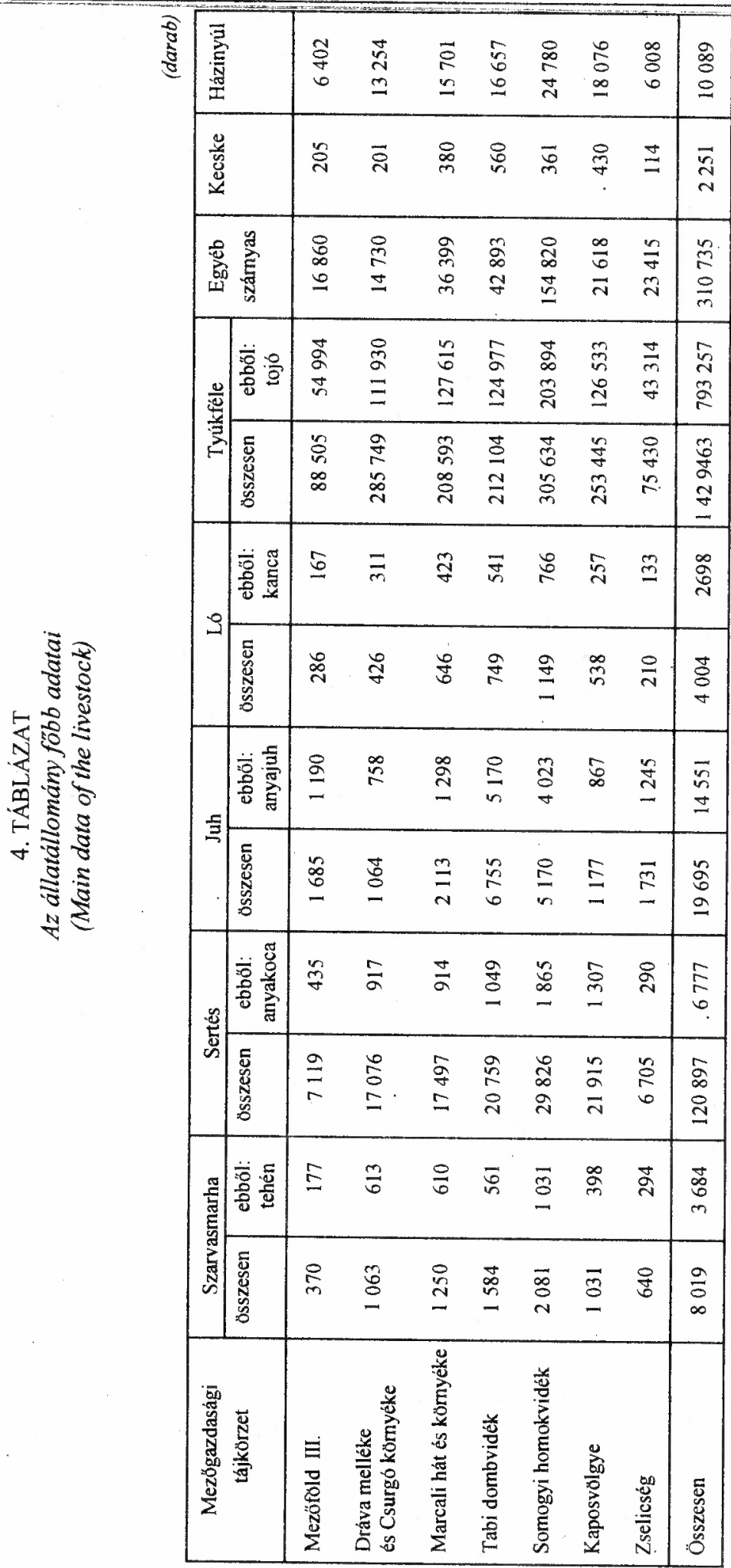


Bokorné Kitanics Tünde : A legeltetéses állattenyésztés meghonositásának lehetőségei és korlátai Somogy megyében Tér és Társadalom 10. évf. 1996/4. 113-123. p.

\section{Somogy megye ökológiai adottságai és a gyepgazdálkodás feltételei}

Gyepgazdálkodási szempontból az éghajlati viszonyoknak van elsődleges szerepułk, azon belül is az évi csapadékmennyiségnek és eloszlásának. A gyep vegetációban egyenletes csapadékellátást igényel. Ezért a legelök hozama a vegetációs időszakban akkor egyenletes, ha a csapadék eloszlása is hasonló. Hazai viszonyok között a gyepek hozama a tájegységre jellemzỏ csapadék mennyiségének és eloszlásának megfelelően nagyon eltérő. A csapadék meghatározó szerepét módosíthatják a talaj hidrológiai viszonyai, elsösorban a talajviz mozgása és szintje. Kedvezó talajvízszint csőkkenti a csapadékhiány káros hatását. Ilyen területek elsősorban a völgyfenék és az árteríletek mélyen fekvớ eyepterilletei.

A pázsitfúfélék elönye, hogy a szélsöséges talajok (futóhomok, meszes-szódás és savanyú szikesek) kivételével különbőző talajtípusokon jól termeszthetők. Természetesen a talaj minósége és a hozamok nagysága közőtt összefüggés mutatható ki.

A gyepgazdálkodás szempontjából előnyt jelent, ha a talajvizszint nem emelkedik -50 $\mathrm{cm}$ fơlé és nem süllyed $-2 \mathrm{~m}$ alá. A gyepgazdálkodás során figyelembe kell venni a domb- és hegyvidéki folyó és patakvölgyek sajátos hidrológiai viszonyait. Itt ugyanis a domborzati viszonyok nagyon befolyásolják a talaj vízgazdálkodását.

A domborzati viszonyok több szempontból befolyásolják a gyepgazdálkodást. A 10\%-nál meredekebb lejtőkön már szántófờldi múvelés nem végezhető és erdő sincs. Itt a gyepgazdálkodás az egyedû̉li hasznosítási mód. E domboldalak azonban vízben szegények. Az itt található gyepéknek a talajvédô, az eróziót megakadályozó szerepe a legfontosabb, de időszakonként juhokkal legeltethetó is.

A hazai gyepteruletek potenciális termóképessége csak 30-50\%-ban van kihasználva. Kedvező természeti viszonyok ko̊zött a jelenlegi hozamok viszonylag kevés ráfordítással megduplázhatók.

Az évi csapadéktól fưggóen az elérhetó szénatermés:

- sik-udde talajokon 15-20 t/ha

- sík-közepes talajokon 12-16 t/ha

- sík-száraz talajokon 9-11 tha.

Lejtós területeken ạ termőképesség 20-30\%-kal kevesebb. A gyakorlat szerint a termóképességet tejtermelésnél 8-10 t/ha, húshasznú tehénállománynál 3-4 t/ha, juhtartásban 2-3 tha hozamig érdemes fokozni,

Az eltartható állatlétszám kiszámításánál tehát feltételezzulk, hogy az állomány téli és nyări tömegtakarmány-szükségletének a $80 \%$-át a gyepterületrỏl legeltetjük le, illetve takarítjuk be. A területen eltartható állatok száma tehát fủgg a gyepterület hozamától és az álltatok egész évi szuikségletétől (5. táblázat).

A gyep termóképességét elsósorban a csapadék mennyisége és eloszlása befolyásolja. A 6. táblázatban osszefoglalva látható Somogy megye ókológiai sajátosságai. Megállapitható, hogy a gyepgazdálkodás szempontjából legkedvezőbb éghajlati vișzonyok a Dráva-mellékén, a Zselicségben, valamint a Somogyi-homokvidéken találhatók. E tájegységek szántóterületeinek aranykorona-értéke kedvezőtlen, 13,9-19,1 AK közötti. A hegy- és dombvidéken a talajok gyenge termőképessége és az alacsony termelési szinvonal erơteljesen korlátozza az ésszerü talajhasználati mód és termelési szerkezet kialakítását. E vidékeken ugyanis sok az ún. feltétlen terulet, ahol csak meghatározott mưvelési ág keretében tơrtênó talajhasznosítás jöhet számításba, és a különbözỏ szántó- 
Bokorné Kitanics Tünde : A legeltetéses állattenyésztés meghonosításának lehetőségei és korlátai Somogy megyében Tér és Társadalom 10. évf. 1996/4. 113-123. p.

földi növények eredményes termesztése is jóval kockázatosabb, mint másutt. A helyes talajhasználatnál a lejtő meredekségével egyenes arányban csőkken a szántóföld és nỏ az erdő, a legelő és a rét aránya. A lejtőszázalék emelkedésével növekednie kell a fedett területek arányának a szántóterület rovására. Hegy- és dombvidéken tehát a gazdálkodás és az ésszerủ talajhasználat fỏ kiindulási elve: szántó és fedett (erdö-, gyep-) terulletek legkedvezőbb arányainak kialakítása a lejtési viszonyoknak megfelelóen. A racionális foldhasználat gyakorlatának a táji adottságokhoz kell igazodnia. A 17-25\%-os lejtóállományban a gyep, a 25\%-on felüli lejtőkategóriában pedig az erdö helyezkedjen el. Visszautalva a 3. ábrán látottakra: a gyepterületek általában a 17 aranykorona alatti minöségü földeken találhatóak. A gyenge, 7-10 AK, barna erdőtalajon is - megfelelo fủfaj megválasztásával (magyar rozsnok, nádképü csenkesz vezérnóvényü gyepeken) biztonságos termést lehet elérni. Mélyebb területeken a réti ecsetpázsitos vezénövényü gyeptípushoz a tarackos tippan és a széleslevelú réti perje társitását szorgalmazták.

\section{TÁBLÁZAT}

Gyepterületek állateltartó-képessége

(Capacity of pastures to sustain livestock)

\begin{tabular}{|c|c|c|c|c|c|c|c|c|c|c|}
\hline \multirow[t]{3}{*}{ Megnevezés } & \multirow{3}{*}{$\begin{array}{c}\text { Egy állat éves } \\
\text { szárazanyag } \\
\text { szukséglet } \\
80 \% \text { a (t) }\end{array}$} & \multicolumn{9}{|c|}{ A gyep szárazanyag termése (tonna) } \\
\hline & & 1 & 2 & 3 & 4 & 5 & 6 & 7 & 8 & 9 \\
\hline & & \multicolumn{9}{|c|}{ eltartható állatok száma (db/ha) } \\
\hline Fejöstehén & 4,38 & 0,23 & 0,45 & 0,68 & 0,93 & 1,20 & 1,38 & 1,60 & 2,83 & 2,03 \\
\hline Hústehén & 3,65 & 0,27 & 0,55 & 0,82 & 1,10 & 1,38 & 1,64 & 1,90 & 2,18 & 2,46 \\
\hline $\begin{array}{l}\text { Növendék - } \\
\text { marha }\end{array}$ & 2,19 & 0,48 & 0,93 & 1,37 & 1,80 & 2,30 & 2,74 & 3,20 & 3,65 & 4,10 \\
\hline Anyajuh & 0,73 & 1,37 & 2,75 & 4,10 & 5,50 & 6,90 & 8,50 & 9,60 & 10,90 & 12,20 \\
\hline
\end{tabular}

\section{TÁBLÁZAT}

Somogy megye ökológiai adottságainak összefoglaló táblázata tájkörzetenként (A comprehensive summary of the ecological endowments of Somogy county by small regions)

\begin{tabular}{|l|c|c|c|}
\hline \multicolumn{1}{|c|}{ Tájkörzet } & $\begin{array}{c}\text { A szántók átlagos } \\
\text { AK-értéke }\end{array}$ & $\begin{array}{c}\text { Csapadékmennyiség } \\
(\mathbf{m m})\end{array}$ & $\begin{array}{c}\text { Napsütés évi ósszege } \\
\text { (óra) }\end{array}$ \\
\hline Mezỏfóld III. & 28,5 & $600-650$ & $2000-2050^{\circ}$ \\
Tabi-dombvidék & 15,6 & $650-700$ & $1950-2000$ \\
Kaposvölgye & 21,8 & $650-750$ & $1950-2000$ \\
Zselicség & 15,3 & $700-750$ & $1900-0950$ \\
Somogyi homokvidék & 13,9 & $700-750$ & $1850-1900$ \\
Marcali-hát & 21,5 & $650-750$ & $1900-0950$ \\
Dráva melléke & 19,1 & $750-800$ & $1800-1850$ \\
\hline
\end{tabular}


Bokorné Kitanics Tünde : A legeltetéses állattenyésztés meghonositásának lehetöségei és korlátai Somogy megyében Tér és Társadalom 10. évf. 1996/4. 113-123. $p$.

Somogy megy ökológiai adottságai - az országoséval ellentétben - megfelelnek a gyep igényeinek. Ennek ellenére a gyep területe évröl-évre csőkken a megyében ( 7 . táblázat).

\author{
7. TÁBLÁZAT \\ A gyepgazdálkodás fontosabb adatainak alakulása \\ (Major data of pasturage)
}

\begin{tabular}{|c|c|c|}
\hline Év & $\begin{array}{c}\text { Terulet } \\
\text { (ezer ha) }\end{array}$ & $\begin{array}{c}\text { Termésátlag } \\
\text { (t/ha) }\end{array}$ \\
\hline $1981-1985$ & 70 & 1,4 \\
$1986-1990$ & 63 & 1,0 \\
1992 & 58 & 0,7 \\
1993 & 58 & 0,6 \\
1994 & 57 & 0,8 \\
\hline
\end{tabular}

Forrás: Somogy megye statisztikai évkőnyve, KSH -, 1994.

A rendelkezésre álló - és a jövőben környezetvédelmi megfontolásból várhatóan növekvő - gyepterületek kihasználtsága rendkívül alacsony, ezért feltétlenül növelni kell a kérỏdző, illetve a gyephasznosító állatfajok létszámát. Ez alatt nem csupán a hagyományos értelemben vett szarvasmarha- és juhtenyésztés fejlesztését értjük, hanem számos új, gyepre alapozott állattenyésztési ágazat és technológia meghonosítását és kifejlesztését, amelyekre Somogy megye természeti adottságainál fogva vállalkozhatunk, és amelyeknek a termékeit a piac igényli. Ilyen ágazatok a:

\title{
Húsmarha
}

A 30-100 ha, jobbára erósen tagolt nagyưzemi módszerekkel nem mủvelhető gyepterületekkel rendelkezó magánvállalkozók számára megélhetést kínál a húsmarhatartás. Kedvező, hogy a vágómarha iránti kereslet és ezzel egyuitt az árak is növekednak. A gazdaságos hegy- és dombvidéki húsmarhatartás feltétele egy olyan fajta, amelyik jól elviseli a mostohább tartási körullményeket, de vágóértéke megfelel a piaci igényeknek. Például hereford, limousine, charolais, egymással vagy a magyartarkával keresztezve. Az állatok legalább 230 napot legeljenek, korszerü legelőhasználat mellett. Egy hektár jól kezelt gyep területén a legeltetési időszakban négy anyatehén eltartható.

\section{Juhtartás}

A juhtenyésztés a legelŏhasznosítás egyik hagyományos formája. Versenyképesebb az ágazat ha a merinónál nagyobb hozamokkal rendelkezỏ és jó minőségủ végterméket szolgáltató intenzívebb hústípusú juhval valósítjuk meg. A szaporaságot a booroola gén bevitelével növelhetjük. Az amerikai suffolk, texel és más extrém hústípusú fajtákkal kiváló vágóértékủ, exportképes hízóbárányok nyerhetók.

A nagyobb kiterjedésü, kis hozamú legelőket csak juhtenyésztés útján lehet gazdaságosan hasznosítani. 
Bokorné Kitanics Tünde : A legeltetéses állattenyésztés meghonosításának lehetőségei és korlátai Somogy megyében

Tér és Társadalom 10. évf. 1996/4. 113-123. p.

TÉT 1996 : 4

\section{Lótartás}

A gyepterületek hasznosításának egy speciális, de ígéretes lehetősége a húslótartás. A világpiacon erőteljesen megnőtt a vágóló, de elsősorban a pecsenyecsikó iránti kereslet. A hidegvérü ló élőtömegtermelésben a legjobb húsmarha állományokkal is versenyképes, és erre a célra a közepes-gyenge minőségú gyepterületek is megfelelnek. A hegy-és dombvidéki lótenyésztés és lótartás célja lehet még:

- a tenyészállatnevelés

- sport- és turisztikai célú haszonállat-elöállítás.

Gím-és dámszarvas tenyésztés

A zárttéri (farmszerú) dámvadtenyésztés a szélsőségesen gyenge legelők hasznosításában versenyképes a többi állatfajjal. Előny, hogy húsuk korlátozás nélkül bevihető a legtőbb országba. A szarvasfélék biológiai igényei jól illeszthetők a rendelkezésünkre álló ơkológiai adottságokhoz.

A kérỏdző állatok és a gyepterületek természetes kapcsolatát büntetlenủl megszakítani nem lehet, ezért az elkövetkezó évtizedekben alapvetỏ feladat a természeti adottságokhoz alkalmazkodó racionális technológiák kidolgozása és mủkődtetése. A gazdaságos mükơtetéshez viszont tulajdonosi érdekeltség és értékarányos piaci viszonyok szukségesek.

\section{Irodalom}

Babinszky M.- Széles Gy. (1994) A gyepgazdálkodás neuralgikus pontjai. A költségtakarékos állattartảsi irányzatok fejlődésének közgazdasági alapkérdései. (Kézirat) PATE, Kaposvár.

Dorgai L. - Laczkó I. (1987) A hegy-és dombvidéki gazdálkodás ökonómiája. Mezőgazdasági Kiadó, Budapest.

Horváth S. (1988) Magyarország megyéi. Kossuth Konyvkiadó, Budapest.

Kitanics T. (1994) A Dél-dunántúli régió ókológiai adottságainak gazdasági elemzése. (OTDK dolgozat) PATE, Kaposvár.

Pécsi M. (1981) A Dunántúli-dombság (Dél-Dunántúl). Magyarország tájfôldrajza 4. kötet. Akadémiai Kiadó, Budapest.

Sarudi Cs. (1994) Az agrártermelés és a területfejlesztés gazdasági osszefüggései Somogy megyében. (Kandidátusi értekezés)

Stefler J. - Horn P. (1995) A magyar állattenyésztés kitorési ponțai. „Agro-2l" füzetek, 11. 168-175. o.

Somogy megye statisztikai évkönyve.Központi Statisztikai Hivatal, Kaposvár, 1995.

Varga G. (1996) A legteljesebb takarmány a gyep. Kistermelök lapja, 9. 4. o.

Vinczeffy I. (1993) Legelō̄e és gyepgazdálkodás. Mezőgazdasági Kiadó, Budapest. 
Bokorné Kitanics Tünde : A legeltetéses állattenyésztés meghonositásának lehetöségei és korlátai Somogy megyében Tér és Társadalom 10. évf. 1996/4. 113-123. $p$.

\title{
THE POSSIBILITIES AND LIMITS OF INTRODUCING GRAZING ANIMAL HUSBANDRY IN SOMOGY COUNTY
}

\author{
TÜNDE BOKOR-KITANICS
}

Approximately two thirds of the territory of Somogy county is hilly areas. The average of the slopes of the county is $8-11 \%$. Compared to the large regions of Hungary, South Transdanubia has the most precipitation, also, its distribution is the most balanced here.

Somogy county is one of the regions in Hungary which have the best ecological endowments for pasturage.

Because of the characteristic hilly surface of the county, a rational land use is necessary. In the case of a right land use, the more steep a slope, the smaller the share of plough-land and the larger the share of forest, pasture and meadow. The ideal case would be if grass were dominant on slopes of $17-25 \%$ and forests on slopes steeper than $25 \%$.

In the territory of Somogy county, large-scale plough-lands can be found on poor quality, steep hillsides. I suggest that grassy areas be planted to replace the plough-lands which have a low fertility. Grass plays an important role in the exchange of lands. The cultivation of steep plough-lands abounds in difficulties, there is a great danger of soil erosion, also, crops are smaller than in plain lands. On slopes, grass is the best protector of the soil.

On the slopes and hillsides, a profitable grazing animal husbandry can be implemented with the right skills and cultivation.

The ecological potential of Somogy county is under-utilised, as both the number of grassy areas and grazing animals is decreasing.

For private entrepreneurs, cattle breeding could provide a certain living.

The traditional way of using the pastures is sheep breeding, which can utilise the larger and less fertile pastures, as well.

A specific way of using the grassy lands is breeding horse for its meat.

The extremely weak pastures could be grazed by red and fallow deer.

The decreasing and derelict grassy areas are still reserves for the Hungarian agriculture. These grassy areas, however, should not be taken out of cultivation but should help us to rationalise agriculture, animal breeding, fodder production and to improve the profitability of producing animal products. 
Tér és Társadalom 10. évf. 1996/4. 124. p.

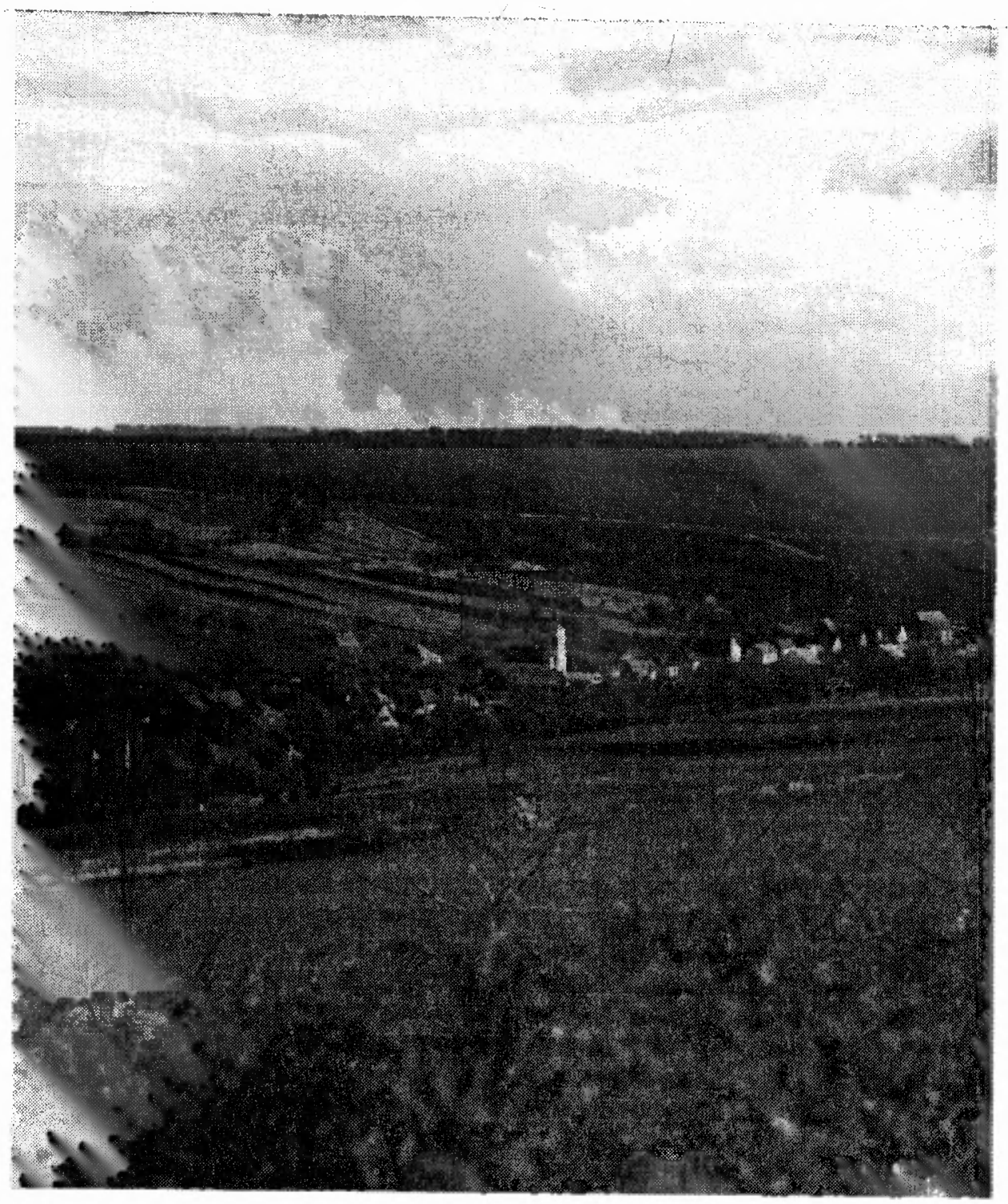

Bőszénfai határ (Körtvélyesi L.) 